Graham as the first full-time Professor of Medicine in the Commonwealth, with authority to hire and fire medical staff. This move stirred up a protracted public commission of inquiry with regard to so-called full-time appointments and the influence of private donors on medical school policy. But after a period of "agitation and discord" the reorganization of the Toronto hospitals resulted in more effective postgraduate training, emphasis on laboratory research coupled with clinical practice and "for the first time in Canada, fair remuneration in the form of salaries paid to full-time, university-based junior researchers in internal medicine."

McGill and Dalhousie, like Toronto, had organized military hospitals that served overseas, staffed by members of the faculty and alumni. At Dalhousie, President Stanley MacKenzie pointed to the wartime devastation from the Halifax explosion, the takeover of medical education buildings for a military hospital and the absence of half of the teaching staff overseas. Thus, all 3 universities presented ample evidence to support Rockefeller's statement that "they have without stint sacrificed themselves, their youth and their resources to the end that democracy might be saved and extended."

Dalhousie received special consideration from the Rockefeller officials; to their credit they viewed the medical school in its context as the only one in the Maritimes. Flexner had almost written it off, but the Foundation officers were more flexible, concerned about the overall upgrading of the school than with the formation of a researchoriented full-time medical faculty.

General Sir Arthur Currie, perhaps the most brilliant military strategist of World War I, became Principal of McGill in May I920. He launched at once a successful centennial campaign to bolster McGill's finances; when the Rockefeller Foundation offered its pledge, Currie had matching funds already in hand so that the program was at once put into action. The rapport between the Rockefeller officers and McGill was most fruitful. Within 3 years, the university completed a biology building for medical sciences, and a pathological institute. Rockefeller funds established McGill's first fulltime professor of medicine, Jonathan Meakins (attracted back from Edinburgh), and university clinic, also headed by Jonathan Meakins, in I924, as well as support for child health and experimental surgery.

Currie worked closely with the Dean of Medicine, Charles Martin, in coordinating the Rockefeller-McGill plans. Fedunkiw logically views the largest Rockefeller grant to McGill in April I932 for its Montreal Neurological Institute (MNI) as a continuing extension of the program initiated in 1920 . Currie supervised the planning, siting and close budget control of Penfield's MNI. Fedunkiw comments that Currie "did not live to see the MNI built." But in fact, on McGill's Founder's Day, 6 October 1933, Sir Arthur carried out a grand military style operation for laying the cornerstone of the MNI, by the Governor General, Lord Bessborough, with many dignitaries in attendance and the Canadian Grenadiers as an honorary guard. A large gap in the front façade represented what would become the main entrance, but the structure already reached up 9 stories. The institute would be officially opened in September 1934 by the Director, Wilder Penfield, and his staff, amidst much academic fanfare.

Penfield, as a Rhodes scholar at Oxford in I9I5, captivated by Osler's charm and erudition, took him as his life-long medical hero. Thus, it marked an apt historical sequence to have the MNI as the crowning feature of the Rockefeller program that was triggered by Osler's note of I9I9, to bring about this great experiment "in promoting medical education in Canada."

\section{William Feindel}

Director Emeritus

Montreal Neurological Institute Montréal, Que.

Honorary Osler Librarian

\title{
One thousand words
}

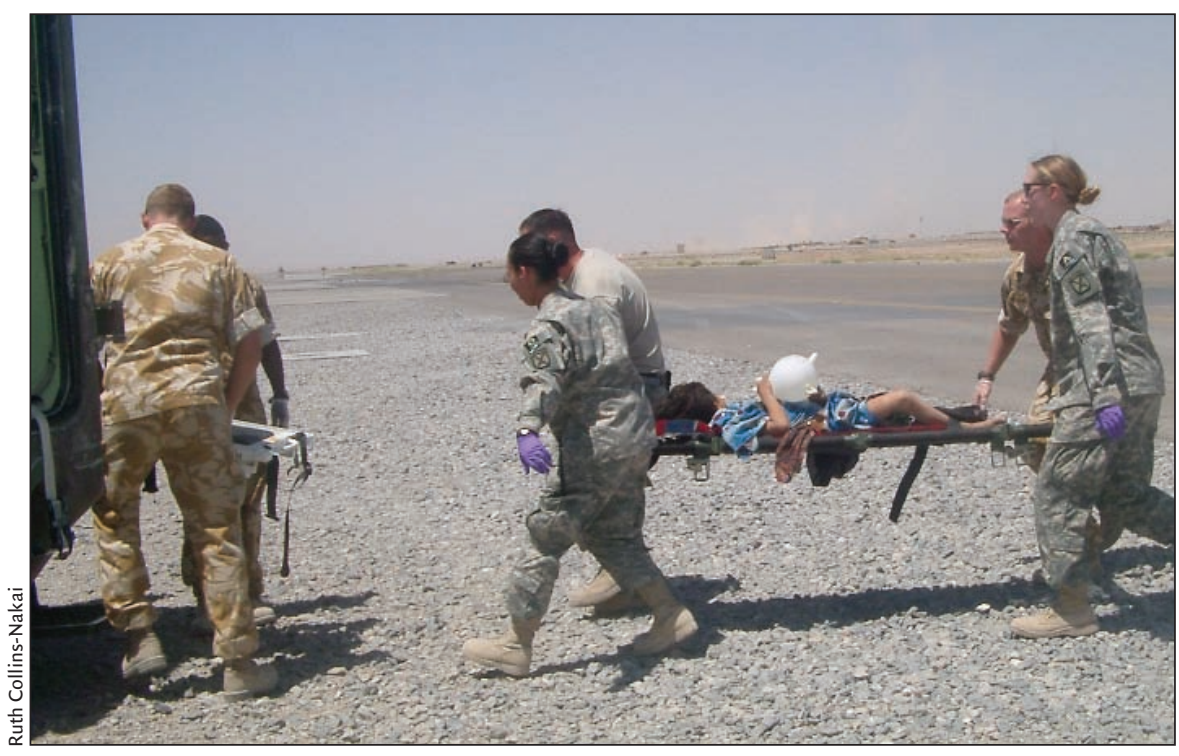

Kandahar Airfield, Afghanistan, 2006: No words, even a thousand, can describe the reality of a child wounded in a war zone. A photo can only give us a glimpse. Here an injured child clutches a surgical glove made into a balloon and painted with a clown's face. She is "caught in the crossfire," "a civilian casualty" in reports in Canada; she is a haunting reality to the physicians who treat her. When not treating armed forces members, much of the current work of military physicians on deployment is in treating civilians. This includes working in villages and the countryside, where access to advanced medical care is otherwise non-existent. - Cathy Younger-Lewis, CMAJ 